\title{
Changes in rheological properties of Edam-type cheese during ripening
}

\author{
Merike Henno ${ }^{1,2}$, Ivi Jõudu ${ }^{1,2}$, Tanel Kaart ${ }^{1,2}$, Andre Veskioja², Meelis Ots ${ }^{1,2}$ \\ ${ }^{1}$ Institute of Veterinary Medicine and Animal Sciences, Estonian University of Life Sciences, Kreutzwaldi 46, \\ Tartu 51006, Estonia \\ ${ }^{2}$ BioCC LLC, Kreutzwaldi 1, 51014 Tartu, Estonia \\ e-mail: ivi.joudu@emu.ee
}

\begin{abstract}
Understanding the parameters affecting the rheological characteristics of cheese enables better regulation and monitoring of cheese consistency and the production of cheese with desired quality. The objectives of this research were to define the linear viscoelastic rheological properties of large scale production Edam-type cheese, to characterize the effect of ripening (from three days to 10 weeks) and to determine the effect of the type of starters, cheese composition and cheese milk on the rheological properties of Edam-type cheese. Changes in the viscoelastic properties were more noticeable in the first four weeks of the ripening period and thereafter stabilized. Highest significant correlations for $\mathrm{G}^{\prime}$ and $\mathrm{G}^{\prime \prime}$ were observed with the ratio of cheese moisture plus fat to protein. The compositional parameters of cheese (moisture, moisture in the non-fat substance and moisture to protein ratio), related to rheological properties, were significantly correlated with vat milk protein content and rennet coagulation properties.
\end{abstract}

Key words: Edam cheese, viscoelastic properties, cheese ripening, cheese composition

\section{Introduction}

The rheological properties of cheese are the key quality attributes for manufacturers, industrial users and consumers, as they affect handling characteristics, texture and eating quality and also the use of cheese as a food ingredient, its ability to retain a given shape and form eyes or to swell (O'Callaghan and Guinee 2004). Cheese rheology in turn is affected by various factors and interactions, including cheese composition, microstructural distributions of fat and protein and the physico-chemical state of its components (Guinee and Kilcawley 2004). All these factors are influenced by initial cheese milk composition, manufacturing protocols, and ripening conditions (Lucey et al. 2003). Understanding the factors affecting the rheological properties of cheese enables better regulation of cheese consistency (Visser 1991) and the production of cheese with desired quality.

A widely used fundamental method to determine the rheological properties of cheese is by small amplitude oscillatory shear (SAOS) measurement. SAOS experiments have been used in order to rheologically characterize different varieties of cheeses (Muliawan and Hatzikiriakos 2007, Alvarenga et al. 2008, Tunick and Van Hekken 2010), compare the rheological properties of low-fat or cheese-like products with original cheeses (Guinee et al. 2000, Oliveira et al. 2011), investigate the effects of milk sources (Pereira et al. 2011) and starter cultures (Hassan et al. 2005) on rheological properties of cheeses, study relationships among rheological and sensorial properties of cheeses (Brown et al. 2003) and also to rheologically characterize cheese ripening (Lucey et al. 2005, Del Nobile et al. 2007, Alvarenga et al. 2008, Karami et al. 2009, Pereira et al. 2011).

To date, there is a lack of reports on the dynamic characterization of changes that occur during ripening of largescale production Edam-type cheeses ripened in plastic film. Sadowska et al. (2009) studied the effects of fat content and storage time on the viscoelastic properties of Dutch-type cheese, based on the results of a stress-relaxation test. They concluded that the main changes in the rheological properties of cheese occurred before their investigated period, which was from 4 to more than 11 weeks.

The objectives of this research were to characterize the effect of ripening (from day 3 to 10 weeks) upon selected rheological properties of cheese, and determine the effect of the type of commercial starters, cheese composition and cheese milk on the rheological properties of large-scale production Edam-type cheese. 


\section{Materials and methods Cheese manufacture}

Fourteen Edam cheese batches were manufactured according to the common production protocol of the largescale production in a dairy plant in Estonia. Ten batches were produced during the period from February to March and four batches in November of the same year. On each experimental day two batches of cheeses (a' 1,275 kg) with different commercial starter cultures - direct vat set (DVS) and bulk set (BS) were produced from the same batch of pooled milk. Edam-type cheese was prepared from cows' milk (pasteurized and standardized to $2.4 \%$ fat) with the precultured cheese starter C92 (CSK Food Enrichment Netherlands) or direct vat set culture C301 (CSK Food Enrichment Netherlands). The milk was renneted $\left(\sim 25 \mathrm{~min}\right.$ at $\left.32{ }^{\circ} \mathrm{C}\right)$ with the addition of $\mathrm{CaCl}_{2}(\mathrm{E}-509)$, and rennet (CHY-MAX, Chr. Hansen Denmark). After curd processing (cutting, removing the first whey, scalding, draining, moulding and pressing) the cheese blocks were brined at $12{ }^{\circ} \mathrm{C}$ for $24 \mathrm{~h}$ (brine solution salt concentration $18-20 \% \mathrm{w} / \mathrm{w}$ ) and were vacuum packed in plastic film. The cheeses were stored for four weeks at $10-12{ }^{\circ} \mathrm{C}$, at a relative air humidity of $80-85 \%$, and subsequently at $6{ }^{\circ} \mathrm{C}$. The $\mathrm{pH}$ values at different steps of cheese production: at renneting, first whey, second whey, after pressing, and before brining, were obtained from the manufacturer.

\section{Sampling}

Before packing, cheese blocks ( $20 \mathrm{~kg}$ ) were divided into five equal parts, which were used for compositional and rheological analyses on day 3 and at weeks 2, 4, 6 and 10 after cheese production. Milk samples were collected during the loading of the cheese vat before adding starter cultures, rennet and calcium chloride.

\section{Compositional analysis}

The cheese milk fat and protein contents were measured at the Milk Analysis Laboratory of Estonian Livestock Performance Recording Ltd, with an automated infrared milk analyzer (CombiFoss ${ }^{\mathrm{TM}}$ FT+; Foss Electric, Hillerød, Denmark).

The cheeses were analyzed for fat, using the Gerber method (ISO 11870/IDF 152, 2009), for protein using the Kjeldahl method (ISO 8968-1/IDF 20-1, 2014) and for total calcium content using a modified titrimetric method (ISO 12081/IDF 36, 2010). For determination of calcium, samples of grated cheese weighing $10 \mathrm{~g}$ (to the nearest $1 \mathrm{mg}$ ) were added to $25 \mathrm{ml}$ of a trichloroacetic acid $20 \%(\mathrm{w} / \mathrm{v})$ solution; the mixture was homogenized at room temperature and was allowed to stand for $30 \mathrm{~min}$. After filtration, $1 \mathrm{ml}$ of clear filtrate weighed (to the nearest $1 \mathrm{mg}$ ) was placed into a centrifuge tube and then the procedure described in the IDF standard method was followed: precipitation of the calcium in the filtrate as calcium oxalate, separation by centrifugation and titration of washed and dissolved precipitate with potassium permanganate.

Changes in $\mathrm{pH}, \mathrm{pH} 4.6$-soluble nitrogen ( $\mathrm{pH} 4.6 \mathrm{SN}$ ), total solids and insoluble (INSOL) Ca contents in the cheese were measured on day 3 and at weeks 2, 4, 6 and 10 after cheese-making. Cheese pH was measured using a pH electrode InLab Expert Pro (Mettler-Toledo AG Schwerzenbach, Switzerland). The proteolysis of cheeses was evaluated by determination of nitrogen solubility at $\mathrm{pH} 4.6$ (Kucroo and Fox 1982). The total solids content of cheese was determined by oven drying (ISO 5534/IDF 004, 2004). The INSOL Ca was calculated from the acid-base titration method as described by Hassan et al. (2004). All compositional tests were carried out in duplicate.

\section{Rheological analysis}

Milk rennet coagulation properties were studied by dynamic small amplitude oscillatory rheology using a Modular Rheometer Physica MCR 301 (Anton Paar Germany GmbH, Ostfilden, Germany), equipped with a double gap cylinder measuring system (DG 26.7/T200/SS, Anton Paar) at $35 \pm 0.1^{\circ} \mathrm{C}$. Milk samples (10 $\mathrm{ml}$ ) were warmed to 35 ${ }^{\circ} \mathrm{C}$, a $0.2 \mathrm{ml} 1 \% \mathrm{v} \mathrm{v}^{-1}$ rennet (CHY-MAX, $600 \mathrm{IMCU} \cdot \mathrm{ml}^{-1}$; Chr. Hansen, Denmark) solution was added and $5 \mathrm{ml}$ of the sample was immediately transferred to the measuring device. A $1 \%$ strain was applied, which is within the linear viscoelastic region of rennet-induced milk gels, and samples were oscillated at a frequency of $1 \mathrm{~Hz}$. The storage modulus $\left(G^{\prime}\right)$, loss modulus $\left(G^{\prime \prime}\right)$ and loss tangents ( $\tan \delta=G^{\prime \prime} / G^{\prime}$ ) were measured at $35^{\circ} \mathrm{C}$ and recorded each $12 \mathrm{~s}$ over $31 \mathrm{~min}$. Rennet coagulation time (RCT) was defined as the time when the aggregated system exceeded a storage modulus value of $1 \mathrm{~Pa}$. Another parameter was derived from the $\mathrm{G}^{\prime}$ profile, the value of storage modulus at 30 min, which was considered to indicate curd firmness $\left(E_{30}\right)$. 
Small amplitude oscillatory shear (SAOS) rheometry was used to study the viscoelastic properties of the cheese on day 3 and at weeks 2, 4, 6 and 10 after cheese-making. SAOS measurements were made in triplicate using a Modular Rheometer Physica MCR 301 (Anton Paar, Germany GmbH, Ostfilden, Germany) with a serrated plate measuring system (PP25/P2-SN17951, Anton Paar). The parameters studied were elastic modulus ( $G^{\prime}$ ), loss modulus (G') and loss tangent $\left(\tan \delta=G^{\prime \prime} / G^{\prime}\right)$. The temperature was kept at $20 \pm 0.1^{\circ} \mathrm{C}$ during all measurements with a Peltier temperature control system (H-PTD200, Anton Paar). The linear viscoelastic region of samples was determined by amplitude sweeps at a constant frequency $\left(10 \mathrm{rad} \cdot \mathrm{s}^{-1}\right)$ and strain range from 0.01 to $100 \%$. A strain in the linear region was then selected and a frequency sweep conducted at the $0.1 \%$ strain and frequency range from 0.1 to $100 \mathrm{rad} \cdot \mathrm{s}^{-1}$. Data were collected at $10 \mathrm{rad} \cdot \mathrm{s}^{-1}$ and used for statistical analyses. Cheese samples from the centre of each cheese were sliced into disc shapes of approximately $1.5 \mathrm{~mm}$ thickness and $20 \mathrm{~mm}$ diameter using a slicer (Topaz 220, Sirman, Padova, Italy) and borer (customized, stainless-steel). The slices were stored in a tightly closed plastic bag at $\sim 6^{\circ} \mathrm{C}$ for at least $3 \mathrm{~h}$ before testing. Cheese samples then were placed on the lower plate and, during loading, normal force readings were kept at approximately $1.0 \mathrm{~N}$ to ensure good contact between the serrated plate and the cheese sample without excessive deformation of the samples. The exposed surface at the edges of the samples were covered with a thin layer of silicone oil (AP 1000, Aldrich - 10842, CAS № 63148-58-3, viscosity 1,000 $\mathrm{mPa} \times \mathrm{s}$,) to prevent them from drying out. The cheeses were allowed to relax for $10 \mathrm{~min}$ after loading.

\section{Statistical analysis}

The mean ( \pm standard error) $\mathrm{pH}$ values during processing, and composition characteristics and viscoelastic properties at different ripening times of cheeses made with DVS and BS were calculated and compared with the pairwise t-test. A two-way ANOVA, considering the effects of repeated measurements of the same batch, was applied to test the overall effects of time, culture and time by culture interactions. The relationships between different composition characteristics and viscoelastic properties at different times were estimated by Spearman correlation analysis. Results at $p<0.05$ were considered statistically significant. All statistical analyses were performed with the statistical package SAS 9.1 (SAS Institute Inc., Cary, NC, USA).

\section{Results and discussion}

\section{Cheese composition and dynamics of $\mathrm{pH}$ during processing}

The compositions of cheeses made with DVS and BS (Table 1) were typical for Edam cheese, whereas the moisture content was lower for BS cheeses as was expected from the different dynamics of the $\mathrm{pH}$ during processing (Table 2). The cheese $\mathrm{pH}$ increased slightly during ripening (Table 1). Within the ripening period, the proportion of INSOL Ca decreased from 75 to $60 \%$ and pH 4.6 SN increased from $\sim 3$ to $15 \%$. These trends were similar to those reported by Lucey et al. (2005) for Cheddar cheese.

\section{Effect of ripening on the viscoelastic properties}

To study the effects of ripening on the viscoelastic properties of Edam type cheese, the cheese samples were analyzed at time points of day 3 and at weeks 2, 4, 6 and 10. The changes in the viscoelastic properties at 10 rad $\mathrm{s}^{-1}\left(\mathrm{G}^{\prime}, \mathrm{G}^{\prime \prime}, \tan \delta\right)$ for both starter types throughout ripening are shown in Figure $1(A, B, C)$. All parameters were significantly $(p<0.001)$ affected by the starter type and ripening time, whereas no significant $(p>0.05)$ interactions between these factors were found. Changes in viscoelastic properties were more noticeable in the first four weeks of the ripening period and stabilized thereafter. Generally the mean values of $G^{\prime}, G^{\prime \prime}$ and $\tan \delta$ for cheeses of both starter types increased at the beginning of ripening, but for five cheeses with both starter types, $G^{\prime}$ and $G^{\prime \prime}$ both suddenly dropped in the second week of ripening (Fig. 1. A', B', C'). The $G^{\prime}$ and $G^{\prime \prime}$ of these cheeses remained lower throughout the entire examined ripening period. As deduced from the increase of tan $\delta$ during the period from day three to week four, the relative increase in the elastic modulus $\left(\mathrm{G}^{\prime}\right)$ was lower than for the loss modulus $\left(G^{\prime \prime}\right)$, indicating a dominant contribution of the viscous component to the viscoelastic properties at the beginning of ripening. The BS cheeses showed higher mean values for G' and G" throughout the entire ripening period. The means of $\tan \delta$ varied between 0.269 and 0.311 for BS cheeses, and between 0.274 and 0.328 for DVS cheeses. Messens et al. (2000) observed quite similar results (from 0.29 to 0.33) for Gouda cheese over a 42-day ripening period. 
Table 1. Composition (\%) of cheeses; $p$-values express the statistical significance of difference between direct vat set (DVS) and bulk set (BS) cultured cheeses according to the pairwise t-test.

\begin{tabular}{|c|c|c|c|}
\hline \multirow[b]{2}{*}{ Composition } & \multicolumn{2}{|c|}{ Mean \pm standard error } & \multirow[t]{2}{*}{$p$-value } \\
\hline & $\operatorname{DVS}(n=7)$ & $\mathrm{BS}(\mathrm{n}=7)$ & \\
\hline Moisture content & $45.1 \pm 0.320$ & $43.5 \pm 0.201$ & 0.002 \\
\hline Moisture in non-fat solids & $59.2 \pm 0.652$ & $57.3 \pm 0.510$ & 0.008 \\
\hline Protein content & $26.6 \pm 0.371$ & $26.8 \pm 0.289$ & 0.577 \\
\hline Fat content & $23.9 \pm 0.485$ & $24.2 \pm 0.342$ & 0.230 \\
\hline Total Ca content & $1.12 \pm 0.009$ & $1.16 \pm 0.024$ & 0.064 \\
\hline \multicolumn{4}{|l|}{ Primary proteolysis } \\
\hline $\mathrm{pH} 4.6 \mathrm{SN}^{\mathrm{a}}$ on day 3 & $3.11 \pm 0.120$ & $3.48 \pm 0.146$ & 0.057 \\
\hline $\mathrm{pH} 4.6 \mathrm{SN}^{\mathrm{a}}$ at week 2 & $5.83 \pm 0.131$ & $6.20 \pm 0.302$ & 0.231 \\
\hline $\mathrm{pH} 4.6 \mathrm{SN}^{\mathrm{a}}$ at week 4 & $8.70 \pm 0.234$ & $9.31 \pm 0.982$ & 0.190 \\
\hline $\mathrm{pH} 4.6 \mathrm{SN}^{\mathrm{a}}$ at week 6 & $10.62 \pm 0.305$ & $11.54 \pm 0.416$ & 0.142 \\
\hline $\mathrm{pH} 4.6 \mathrm{SN}^{\mathrm{a}}$ at week 10 & $13.97 \pm 0.183$ & $14.94 \pm 0.410$ & 0.103 \\
\hline \multicolumn{4}{|c|}{$\mathrm{pH}$ and insoluble $\mathrm{Ca}$ (at the different time points) } \\
\hline pH on day 3 & $5.34 \pm 0.029$ & $5.46 \pm 0.030$ & 0.003 \\
\hline $\mathrm{pH}$ at week 2 & $5.39 \pm 0.027$ & $5.47 \pm 0.032$ & 0.016 \\
\hline $\mathrm{pH}$ at week 4 & $5.40 \pm 0.016$ & $5.48 \pm 0.027$ & 0.031 \\
\hline $\mathrm{pH}$ at week 6 & $5.40 \pm 0.017$ & $5.45 \pm 0.026$ & 0.091 \\
\hline $\mathrm{pH}$ at week 10 & $5.40 \pm 0.016$ & $5.48 \pm 0.031$ & 0.037 \\
\hline INSOL Ca ${ }^{b}$ on day 3 & $75.5 \pm 1.436$ & $75.5 \pm 1.481$ & 0.998 \\
\hline INSOL Ca ${ }^{b}$ at week 2 & $70.8 \pm 1.313$ & $70.7 \pm 1.326$ & 0.954 \\
\hline INSOL Ca ${ }^{b}$ at week 4 & $67.8 \pm 1.524$ & $66.9 \pm 1.327$ & 0.736 \\
\hline INSOL Cab at week 6 & $64.0 \pm 1.361$ & $63.2 \pm 1.232$ & 0.736 \\
\hline INSOL Ca ${ }^{\text {b }}$ at week 10 & $61.4 \pm 1.380$ & $60.4 \pm 1.188$ & 0.640 \\
\hline
\end{tabular}

a $\mathrm{pH} 4.6$ soluble nitrogen as a \% of total nitrogen in the cheese; ${ }^{\mathrm{b}}$ Insoluble $\mathrm{Ca}$ as a \% of total Ca in the cheese

Table 2. Mean $\mathrm{pH}$ values during processing ( \pm standard error) and statistical significance of difference between direct vat and bulk set culture according to the pairwise t-test.

\begin{tabular}{llll}
\hline & Direct vat set culture & Bulk set culture & $p$-value \\
\hline $\mathrm{pH}$ at renneting & $6.59 \pm 0.010$ & $6.57 \pm 0.008$ & 0.116 \\
$\mathrm{pH}$ of the first whey & $6.55 \pm 0.013$ & $6.51 \pm 0.012$ & 0.030 \\
$\mathrm{pH}$ of the second whey & $6.48 \pm 0.022$ & $6.42 \pm 0.020$ & 0.047 \\
$\mathrm{pH}$ after pressing & $5.90 \pm 0.045$ & $5.84 \pm 0.045$ & 0.398 \\
$\mathrm{pH}$ before brining & $5.48 \pm 0.053$ & $5.53 \pm 0.046$ & 0.465 \\
\hline
\end{tabular}

It is widely recognized that the changes in cheese elasticity during the early stages of ripening result mainly from the combined effects of primary proteolysis, slow solubilisation of colloidal calcium phosphate and increasing protein hydration by absorbing serum into the matrix from the fat-serum channels (Lucey at al. 2003). In the current study no significant differences for INSOL Ca and pH 4.6 SN for cheese groups with and without the drop of $\mathrm{G}^{\prime}$ in the second week of ripening were observed (Table 3). The main differences for these two groups were significantly higher contents of fat, protein, protein/fat ratio and superior coagulation properties of the bulk tank milk of the cheese group without the drop in $\mathrm{G}^{\prime}$. These differences in milk composition resulted from different raw milk compositions in the different manufacturing periods and cheese milk standardization method used (milk was not standardized to protein/fat ratio). The cheese milk differences for cheese groups with and without the drop of $G^{\prime}$ in the second week of ripening were associated with trends for a higher content of protein $(p=0.052)$ and moisture+fat/ protein ratio ( $p=0.072$ ) for the cheeses without a drop in $\mathrm{G}^{\prime}$. Similar sharp decreases in $\mathrm{G}^{\prime}$ during the first month of ripening have previously been reported by Hassen et al. (2005) for reduced-fat Cheddar cheeses. Those authors associated this decrease in $\mathrm{G}^{\prime}$ and $\mathrm{G}^{\prime \prime}$ with water redistribution in the first month of ripening. The current authors propose that the different dynamics of the cheeses' rheological properties resulted from dissimilar protein contents and coagulation properties of cheese milk, accompanied with variation in the quantity and quality of bonds between caseins. While the drop in $\mathrm{G}^{\prime}$ at the beginning of maturation seems to influence the viscoelastic properties of cheese through the entire ripening period, further studies are needed to clarify the exact reason for this. 

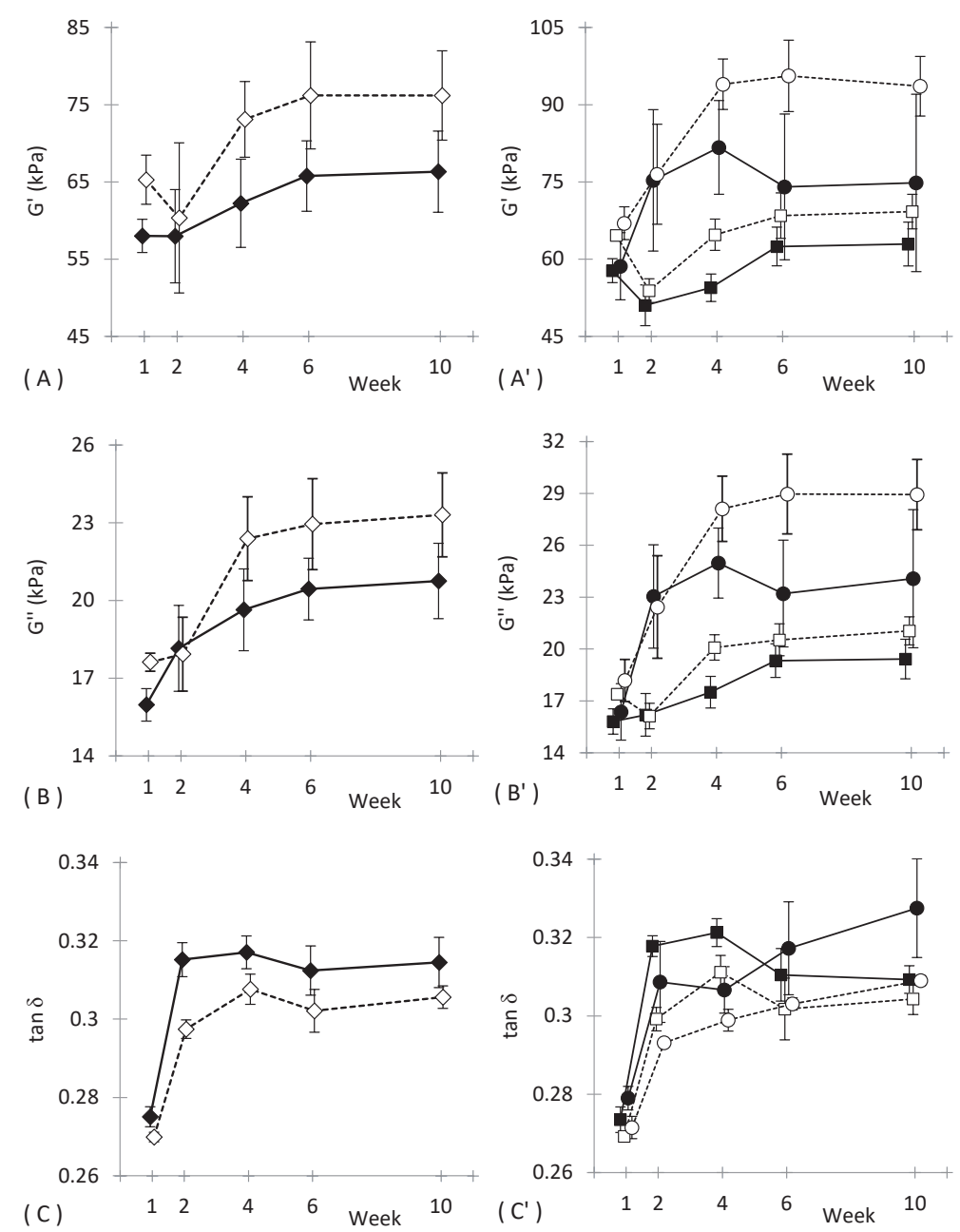

Fig.1. Changes in storage modulus $\left(G^{\prime}\right)$, loss modulus $\left(G^{\prime \prime}\right)$ and loss tangent $(\tan \delta)$ at 10 rad $\mathrm{s}^{-1}$ of Edam type cheeses processed with bulk set culture (open symbols; $\mathrm{n}=7$ ) and direct vat set culture (filled symbols; $n=7$ ). The results are expressed as overall means (figures A, B and C) and means of five BS and five DVS cheeses with drop of G' and G" in the second week (squares in figures $A^{\prime}, B^{\prime}$ and $C^{\prime}$ ) and two BS and two DVS cheeses without drop (circles in figures $A^{\prime}, B^{\prime}$ and $C^{\prime}$ ). The error bars represent the standard error for each time point.

Table 3. Composition (\%) of cheese milk and cheeses without (CDN) and with (CD) sudden drop of elastic ( $\left.G^{\prime}\right)$ and loss $\left(G^{\prime \prime}\right)$ modulus in the second week of ripening

\begin{tabular}{llll}
\hline & \multicolumn{2}{l}{ Mean \pm standard error } & $p$-value \\
\hline Milk & $\mathrm{CDN}(\mathrm{n}=4)$ & $\mathrm{CD}(\mathrm{n}=10)$ & \\
Fat content & $2.43 \pm 0.007$ & $2.37 \pm 0.014$ & 0.003 \\
Protein content & $3.49 \pm 0.006$ & $3.16 \pm 0.012$ & $<0.001$ \\
Protein/fat & $1.44 \pm 0.005$ & $1.33 \pm 0.010$ & $<0.001$ \\
Rennet coagulation time (min) & $7.06 \pm 0.430$ & $9.24 \pm 0.331$ & 0.006 \\
Curd firmness (Pa) & $65.1 \pm 3.122$ & $44.1 \pm 1.197$ & 0.003 \\
Cheese & & & \\
Protein content & $27.3 \pm 0.322$ & $26.4 \pm 0.249$ & 0.052 \\
Fat content & $23.5 \pm 0.402$ & $24.2 \pm 0.362$ & 0.240 \\
Moisture content & $43.8 \pm 0.594$ & $44.5 \pm 0.327$ & 0.392 \\
(Moisture + fat)/protein & $2.46 \pm 0.053$ & $2.61 \pm 0.037$ & 0.072 \\
pH 4.6 SN & $6.19 \pm 0.239$ & $5.94 \pm 0.215$ & 0.463 \\
INSOL Ca & $69.2 \pm 1.214$ & $71.4 \pm 0.550$ & 0.131 \\
\hline${ }^{\mathrm{a} p H} 4.6$ soluble nitrogen as a \% of total nitrogen in the cheese; ${ }^{\circ}$ Insoluble Ca as a \% of total Ca in the cheese
\end{tabular}


Increases in $G^{\prime}$ and $G^{\prime \prime}$ (measuring temperature $\leq 25^{\circ} \mathrm{C}$ ) with ripening have been previously associated with different causes, while for $\tan \delta$ different trends have been observed. An increase in $\mathrm{G}^{\prime}$ and $\mathrm{G}^{\prime}$ ' in conjunction with a decrease in $\tan \delta$, due to the moisture losses during ripening, have been reported by Tunick and Van Hekken (2002) for Gouda/Old Amsterdam and by Messens et al. (2000) for untreated Gouda cheese. In the current study cheeses were ripened in plastic film and mean moisture concentrations on day 3 (DVS - 44.99\%; BS - 43.69\%) and week 10 (DVS - 45.01\%; BS - 43.55\%) for both cheese groups were not significantly ( $>>0.05)$ different. Karami et al. (2009) ascribed the increase in elasticity (increase in $\mathrm{G}^{\prime}$ and $\mathrm{G}^{\prime \prime}$ and decrease in tan $\delta$ ) of Iranian UF-Feta cheese during the ripening period to proteolysis and lipolysis reactions leading to a rearranged protein matrix due to disruption of the fat globules (a decrease in the number of weak points) and an increase in the number of cross-links between strands of casein. Van Hekken et al. (2004) observed that a significant increase in the viscoelastic properties (G', G' and complex viscosity) of Monterey Jack goat's milk cheese was strongly correlated with proteolysis. Increased proteolysis resulted in an altered, more flexible cheese protein matrix and softer cheese. Lucey et al. (2005) reported that the $\mathrm{G}^{\prime}$ value of Cheddar cheese increased during ripening if measured at $5{ }^{\circ} \mathrm{C}$, however $\tan \delta$ values were similar at all studied ripening times. They proposed that proteolysis and loss of INSOL Ca increased the flexibility of the casein particles at low temperatures, due to the weaker hydrophobic interactions and the increase in the contact area between casein particles, resulting in an increase in the $\mathrm{G}^{\prime}$ value (correlations between INSOL Ca or pH 4.6 SN and G', respectively $r=-0.50$ and $r=0.63$ ). Compared to Lucey et al. (2005) the current study found somewhat weaker but nevertheless significant correlations between these parameters and $\mathrm{G}^{\prime}$, but the G' correlations were lower than correlations between INSOL Ca or pH 4.6 SN with either G" or tan $\delta$ (Table 4). As a higher tan $\delta$ indicates an increased relative number and relaxation behaviour (shorter life time) of protein bonds (Roefs et al. 1990, Luyten et al 1991) it was presumed that during the ripening (four weeks) of Edam cheese, proteolysis and loss of INSOL Ca led to an increase in the contact area between casein particles accompanied with an increased number of casein-casein bonds and altered bonds structure resulting in a relatively lower increase in the $\mathrm{G}^{\prime}$ value than $\mathrm{G}^{\prime \prime}$.

Table 4. Spearman correlation coefficients between viscoelastic and some compositional parameters during cheese ripening

\begin{tabular}{|c|c|c|c|}
\hline & Elastic modulus ( $\left.G^{\prime}\right)$ & Loss modulus (G') & Loss tangent $\left(\tan \delta=G^{\prime \prime} / G^{\prime}\right)$ \\
\hline INSOL Ca ${ }^{a}$ & $-0.42 * * *$ & $-0.57 * * *$ & $-0.54 * * *$ \\
\hline $\mathrm{pH} 4.6 \mathrm{SN}^{\mathrm{b}}$ & $0.34 * *$ & $0.48 * * *$ & $0.50 * * *$ \\
\hline
\end{tabular}

\section{Effect of physicochemical parameters of cheese on viscoelastic properties}

To estimate the effect of a range of physicochemical parameters of cheese on the viscoelastic properties ( $G^{\prime}, G^{\prime \prime}$ and $\tan \delta$; at $10 \mathrm{rad} \mathrm{s}^{-1}$ ) throughout ripening, correlation coefficients were calculated (Fig. 2). As was expected from previous reports (Visser 1991, Tunick 2010), the strongest significant correlations were observed between viscoelatic characteristics and cheese composition parameters, reflecting relationships between the total filler (fat plus moisture) and the protein matrix. This is because, with a greater density of protein in the network, the concentration of crosslinking material increases. The correlation coefficients between the cheese moisture plus fat to protein ratio and $G^{\prime}$ varied from -0.69 to -0.83 and for $G^{\prime \prime}$ from -0.69 to -0.84 . Similar correlations with $G^{\prime}$ and G" were found with the ratio of moisture to protein and with moisture in the non-fat substance (MNFS). Fat in dry matter (FDM), protein and moisture contents were also strongly correlated with modules $\mathrm{G}^{\prime}$ and $\mathrm{G}^{\prime \prime}$, whereas correlations between cheese fat content and viscoelacity were not significant, except in week 10 with $\mathrm{G}^{\prime}$ and $\mathrm{G}^{\prime \prime}$. Similarly to the results reported here, Rogers et al. (2010) found a low dependence of the storage modulus on the fat content at $20^{\circ} \mathrm{C}$ and $25^{\circ} \mathrm{C}$. Visser (1991) pointed out that at intermediate temperatures the stiffness of the cheese is not affected by the amount of fat present, as at these temperatures the stiffness of the fat globules is the same as that of the matrix.

Most of the compositional parameters of cheese (moisture, moisture to protein ratio, MNFS) related to rheological properties were significantly correlated with the $\mathrm{pH}$ of the second whey, and also with some of the cheese milk compositional parameters (protein, protein to fat ratio,) and coagulation properties (Table 5). Lower moisture (Table 1) and MNFS contents caused by lower pH values during processing (Table 2) probably lead to somewhat higher average elasticity of BS cheeses than that for DVS cheeses with higher moisture content (Fig. 1). 
Table 5. Spearman correlation coefficients between milk and cheese parameters

\begin{tabular}{|c|c|c|c|c|c|}
\hline & Protein $^{M}$ & Protein/fat ${ }^{\mathrm{M}}$ & $\mathrm{E}_{30}{ }^{\mathrm{M}}$ & $\mathrm{pH}_{\mathrm{w} 1}$ & $\mathrm{pH}_{\mathrm{w} 2}$ \\
\hline Moisture ${ }^{\mathrm{ch}}$ & -0.33 & -0.39 & -0.45 & $0.54 *$ & $0.67 * *$ \\
\hline Moisture/protein ${ }^{\mathrm{ch}}$ & $-0.56^{*}$ & $-0.67 * *$ & $-0.63 *$ & 0.48 & $0.64 *$ \\
\hline MNFS $^{\text {ch }}$ & -0.43 & -0.47 & -0.49 & 0.27 & $0.54 *$ \\
\hline Moisture+fat/protein ${ }^{c h}$ & $-0.60 *$ & $-0.69 * *$ & $-0.64 *$ & 0.26 & 0.51 \\
\hline
\end{tabular}

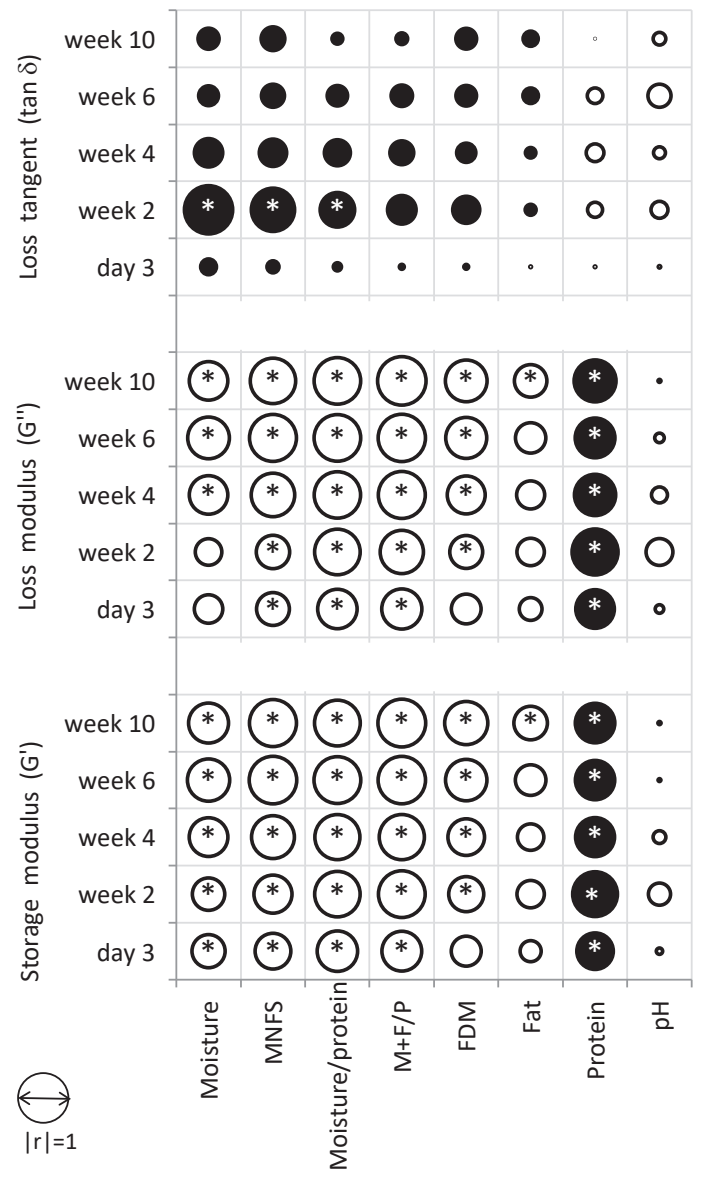

Fig. 2. Spearman correlation coefficients between compositional and rheological parameters by week of aging. White circles represent negative, black circles positive correlation coefficients, diameter of circles correspond to value and * indicates statistical significance $(p<0.05)$. (MNFS = moisture in non-fat substance, $\mathrm{M}+\mathrm{F} / \mathrm{P}=$ moisture plus fat to protein ratio, $\mathrm{FDM}=$ fat in dry matter)

\section{Conclusions}

The rheological properties of cheese affect handling characteristics, texture and eating quality of cheese, and understanding the factors affecting the rheological properties of cheese is important for the production of cheese with desired quality. Viscoelastic properties ( $\mathrm{G}^{\prime}, \mathrm{G}^{\prime \prime}$ and $\tan \delta ; 10 \mathrm{rad} \mathrm{s}^{-1}$ ) of Edam type cheeses were affected by the starter type and ripening time. Higher average elasticity of BC cheeses was attributed to lower moisture and MNFS contents caused by lower pH values during processing. As changes in viscoelastic properties (G', $G^{\prime \prime}$ and tan $\delta)$ were more noticeable in the first four weeks of the ripening period, and stabilized thereafter, it is important for producers to consider this in quality checking and decision-making. There was a significant effect of cheese milk composition on the rheological properties of cheese. The compositional parameters of cheese related to rheological properties (moisture, MNFS, moisture to protein ratio) were correlated with milk protein content, protein to fat ratio and rennet coagulation properties. Different dynamics of cheeses' rheological properties (drop in $\mathrm{G}^{\prime}$ at the beginning of maturation) resulted from dissimilar protein contents and coagulation properties of cheese milk. 
While the drop in $\mathrm{G}^{\prime}$ at the beginning of ripening influenced the viscoelastic properties of cheeses through the entire ripening period, further studies are needed to clarify the reason for this phenomenon with regard to the relative importance of cheese milk protein to fat ratio (milk standardization) and coagulation properties.

\section{Acknowledgements}

This research was carried out by the Bio-Competence Centre of Healthy Dairy Products (BioCC LLC), and co-financed by the European Community's Regional Development Fund within the framework of the Competence Centre Programme of Enterprise Estonia, project no. EU30002, EU48686. We are grateful to AS E-Piim Production dairy at Põltsamaa, Estonia, for manufacturing the experimental cheeses.

\section{References}

Alvarenga, N., Silva, P., Garcia, J. \& Sousa, I. (2008). Estimation of Serpa cheese ripening time using multiple linear regression (MLR) considering rheological, physical and chemical data. Journal of Dairy Research 75: 233-239. https://doi.org/10.1017/ S0022029908003191

Brown, J.A., Foegeding, E.A., Daubert, C.R., Drake, M.A. \& Gumpertz, M. 2003. Relationships among rheological and sensorial properties of young cheeses. Journal of Dairy Science 86: 3054-3067. https://doi.org/10.3168/jds.S0022-0302(03)73905-8

Del Nobile, M.A., Chillo, S., Falcone, P.M., Laverse, J., Pati, S. \& Baiano, A. 2007. Textural changes of Canestrello Pugliese cheese measured during storage. Journal of Food Engineering 83: 621-628. https://doi.org/10.1016/j.jfoodeng.2007.04.026

Guinee, T.P., Auty, M.A.E., Mullins, C., Corcoran, M.O. \& Mulholland, E.O. 2000. Preliminary observations on effects of fat content and degree of fat emulsification on the structure-functional relationship of Cheddar-type cheese. Journal of Texture Studies 31: 645-663. https://doi.org/10.1111/j.1745-4603.2000.tb01026.x

Guinee, T.P. \& Kilcawley, K.N. 2004. Cheese as an ingredient. In: Fox, P.F., McSweeney, P.L.H., Cogan, T.M. \& Guinee, T.P. (eds.). Cheese: Chemistry, Physics and Microbiology. Vol. 2. Major Cheese Varieties. Elsevier Academic Press, London. p. 395-428. https://doi.org/10.1016/S1874-558X(04)80053-8

Hassan, A.N., Awad, S. \& Muthukumarappan, K. 2005. Effects of exopolysaccaride-producing cultures on the viscoelastic properties of reduced-fat Cheddar cheese. Journal of Dairy Science 88: 4221-4227. https://doi.org/10.3168/jds.S0022-0302(05)73108-8

Hassan, A., Johnson, M.E. \& Lucey, J.A. 2004. Changes in the proportions of soluble and insoluble calcium during the ripening of Cheddar cheese. Journal of Dairy Science 87: 854-862. https://doi.org/10.3168/jds.S0022-0302(04)73229-4

ISO 11870 / IDF 152. 2009. Milk and milk products - Determination of fat content - General guidance on the use of butyrometric methods.

ISO 12081 / IDF 36. 2010. Milk. - Determination of calcium content. - Titrimetric method.

ISO 5534 / IDF 004. 2004. Cheese and processed cheese - Determination of the total solids content (Reference Method).

ISO 8968-1 / IDF 20-1. 2014. Milk and milk products - Determination of nitrogen content - Part 1: Kjeldahl principle and crude protein calculation.

Karami, M., Ehsani, M.R., Mousavi, S.M., Rezaei, K. \& Safari, M. 2009. Changes in the rheological properties of Iranian UF-Feta cheese during ripening. Food Chemistry 112: 539-544. https://doi.org/10.1016/j.foodchem.2008.06.003

Kucroo, C.N. \& Fox, P.F. 1982. Soluble nitrogen in Cheddar cheese: Comparison of extraction procedures. Milchwissenschaft 37 : 331-335.

Lucey, J.A., Johnson, M.E. \& Horne, D.S. 2003. Invited review: Perspectives on the basis of the rheology and texture properties of cheese. Journal of Dairy Science 86: 2725-2743. https://doi.org/10.3168/jds.S0022-0302(03)73869-7

Lucey, J.A., Mishra, R., Hassan, A. \& Johnson, M.E. 2005. Rheological and calcium equilibrium changes during the ripening of Cheddar cheese. International Dairy Journal 15: 645-653. https://doi.org/10.1016/j.idairyj.2004.08.018

Luyten, H., van Vliet, T. \& Walstra, P. 1991. Characterization of the consistency of Gouda cheese: Rheological properties. Netherlands Milk and Dairy Journal 45: 33-53.

Messens, W., van de Walle, D., Arevalo, J., Dewettinck, K. \& Huyghebaert, A. 2000. Rheological properties of high-pressure-treated Gouda cheese. International Dairy Journal 10: 359-367. https://doi.org/10.1016/S0958-6946(00)00066-2

Muliawan, E.B. \& Hatzikiriakos, S.G. 2007. Rheology of mozzarella cheese. International Dairy Journal 17: 1063-1072. https:// doi.org/10.1016/j.idairyj.2007.01.003

O'Callaghan, D.J. \& Guinee, T.P. 2004. Rheology and texture of cheeses. In: Fox, P.F., McSweeney, P.L.H., Cogan, T.M. \& Guinee, T.P. (eds.). Cheese: Chemistry, Physics and Microbiology. Vol. 1. General Aspects. Elsevier Academic Press, London. p. 511-540. https://doi.org/10.1016/S1874-558X(04)80080-0

Oliveira, N.M., Dourado, F.Q., Peres, A.M., Silva, M.V., Maia, J.M. \& Teixeira, J.A. 2011. Effect of guar gum on the physicochemical, thermal, rheological and textural properties of green Edam cheese. Food and Bioprocess Technology 4: 1414-1421. https:// doi.org/10.1007/s11947-010-0324-6

Pereira, C.I., Franco, M.I., Gomes, A.M.P. \& Malcata, F.X. 2011. Microbiological, rheological and sensory characterization of Portuguese model cheeses manufactured from several milk sources. LWT - Food Science and Technology 44: 2244-2252. https:// doi.org/10.1016/j.Iwt.2011.06.013 
Roefs, S.P.F.M., van Vliet, T., van den Bijgaart, H.J.C.M., de Groot-Mostert, A.E.A. \& Walstra, P. 1990. Structure of casein gels made by combined acidification and rennet action. Netherlands Milk and Dairy Journal 44: 159-188.

Rogers, N.R., McMahon, D.J., Daubert, C.R., Berry, T.K. \& Foegeding, E.A. 2010. Rheological properties and microstructure of Cheddar cheese made with different fat contents. Journal of Dairy Science 93: 4565-4576. https://doi.org/10.3168/jds.2010-3494

Sadowska, J., Białobrzewski, I., Jeliński, T. \& Markowski, M. 2009. Effect of fat content and storage time on the rheological properties of Dutch-type cheese. Journal of Food Engineering 94: 254-259. https://doi.org/10.1016/j.jfoodeng.2009.03.015

Tunick, M.H. 2010. Activation energy measurement in rheological analysis of cheese. International Dairy Journal 20: 680-685. https://doi.org/10.1016/j.idairyj.2010.03.010

Tunick, M.H. \& van Hekken, D.L. 2002. Torsion gelometry of cheese. Journal of Dairy Science 85: 2743-2749. https://doi.org/10.3168/ jds.S0022-0302(02)74361-0

Tunick, M.H. \& Van Hekken, D.L. 2010. Rheology and texture of commercial Questo Fresco cheeses made from raw and pasteurized milk. Journal of Food Quality 33: 204-215. https://doi.org/10.1111/j.1745-4557.2010.00331.x

van Hekken, D.L., Tunick, M.H. \& Park, Y.W. 2004. Rheological and proteolytic properties of Monterey Jack goat's milk cheese during aging. Journal of Agricultural and Food Chemistry 52: 5372-5377. https://doi.org/10.1021/jf049918q

Visser, J. 1991. Factors affecting the rheological and fracture properties of hard and semi-hard cheese. In: Walstra, P. (ed.). Rheological and Fracture Properties of Cheese. International Dairy Federation, Brussel, Belgium. p. 49-61. 